\title{
Research on the Relationship between Customer Knowledge, Customer Participation Innovation and Customer Experience in Social Media Environment
}

\author{
Zhu Ying \\ School of Information Technology and Management \\ University of International Business and Economics
}

\begin{abstract}
In order to enhance customer experience and manage customer knowledge in social media environment, this paper establishes the mechanism of customer experience impact. After reviewing the literature related to customer experience, we found that customer knowledge and customer engagement innovation are important factors influencing the customer experience, and creatively took into account the influencing factors of the social media environment. We concluded that customer knowledge and virtual customer environment can influence users to participate in innovation, and customer knowledge can influence customer experience through customer participation in innovation. This article can provide new ideas for how to manage customer knowledge and enhance user experience, which can increase user stickiness and improve business performance.
\end{abstract}

Keywords-Customer knowledge; Customer participation in innovation; Customer experience

\section{INTRODUCTION}

Social media networks such as social media and virtual communities developed on the Internet have led to the enrichment of interactive platforms, creating many interactive opportunities between customers and enterprises, enabling customers to have more ways to express their true feelings. With the development of the social media network, customers began to participate in the company's products, services and other innovations. At the same time, enterprise innovation has gradually changed from self-innovation to openness, and enterprises have paid more attention to the management of customer knowledge. Companies use social media to create good interactive conditions to enhance the customer experience and gain a sustainable competitive advantage. Some companies are also working hard to enhance the customer experience in the process of customer participation in innovation. For example, the XiaoMi community includes not only enable customer participate in product innovation but also pursue customer experience. Starbucks Coffee's "My Starbucks Ideas" aim to attract customers to design coffee so as to enhance the customer experience.

In the process of product development, customers use their own relevant knowledge to participate in the product designing, product testing and product improvement [1]. However, does the customer have more knowledge in the participation innovation and will have a better product experience? In the marketing activities, enterprise knowledge management focuses on customer knowledge, that is, customer knowledge about products or services. Most of researchers focus on how to make customer information and knowledge "flow into" enterprises more effectively. However, there is not much attention to how to make knowledge "out of" the enterprise more effectively.

Influence mechanism of customer knowledge, customer participation innovation and customer experience in the social media environment is worth considering. Whether the company should deliver more relevant knowledge to customers, so as to achieve high experience value in the process of customer participation in product innovation. In addition, considering in the social media environment whether exist new factors influence the overall process is also the important content of this article.

\section{LITERATURE REVIEW}

\section{A. Customer Knowledge}

The customer knowledge shows the high-quality resources in the customer group and becomes an important part of the enterprise knowledge [2]. However, because customer knowledge contains a wide range of content, there is no uniform definition in the academic community. Currently the most widely used is the definition of Bueren and Schierholz , which divide into three categories [3], knowledge of customers need, knowledge about customers and knowledge from customers. Knowledge of customers need refers to information about the company's products, services and market conditions, knowledge about customers refers to the basic information such as demographic information and historical purchase information, knowledge from customers refers to the customer's product or service information describing the company or competitor, including customer thoughts, suggestions, feedback, complaints, expectations, etc.

Heather A. Smith further analyzed the dimensions of customer knowledge, and believed that the dimension of customer knowledge also include knowledge of co-creation [4]. Some other scholars divide customer knowledge into product or technical aspects, customer knowledge at the system level 
and customer knowledge at the strategic level. In short, more and more companies are aware of the importance of customer knowledge, starting paying attention to the value created by customers. The customer knowledge mentioned in this article refers to the knowledge required during the interaction between the customer and the enterprise, including information about the product, the market and the supplier.

\section{B. Customer Participation in Innovation}

As enterprises become more competitive, companies are gradually thinking about how to obtain more innovative ideas. Customer participation in innovation is a new measure of corporate innovation strategy. Enterprises and customers cooperate to develop new products or services by using the knowledge, experiences and skills of customers to interact with the resources provided by the company [5]. Customer engagement is also a form of value creation in which customers participate in activities or processes, which usually dominated by the business, and the customer becomes a cooperative producer. For the enterprise, customer participation in innovation enable them understand customer demand preferences and develop customer-oriented design, which has implications for the development of new products [6]. For the customer, they participate in the process of product development and can gain the reward of enjoyment or utilitarianism [7]. For the phase of customers participate in innovation activities, scholars have different opinions. Marianne and Laurence divide the innovation process into four phases, include requirements identification, requirements interpretation, innovative product development and product validation [8]. Some scholars believed customers participate in the innovation process divided into three stages, the creation stage, the manufacturing stage and the commercialization and marketing stage. This article focuses on the creation stage and the stage of testing the new product.

\section{Customer Experience}

Pursuing a good customer experience is one of the goals of the companies. Joseph, the founders and advocates of the experience economy, defined customer experience as the individuals participate the event in a personalized way [9]. Another experiential marketing advocate, Skett believes that the customer experience is a collection of sensory stimuli, information and emotions between the company and the customer. Some researchers find that customer experience is an interactive process of behavior between consumers and companies to meet the needs of consumers' intrinsic experience.

Rose showed that it is necessary to provide the right customer experience by successful empirical research on online brands [10]. In the context of social media, this paper argues that customer experience is the psychological state that customers use their knowledge to experience the entire innovation process through social media including virtual communities. This article will cite the concepts of domestic scholars $\mathrm{Li}$ and Fan to divide the customer experience into functional experience, emotional experience and social experience. Functional experience refers to the subjective recognition that the functional characteristics of a product or service need to satisfy the customer; the emotional experience is the process of participating in the innovation process between the customer and the enterprise or the customer and the customer; the social experience is the social demand that the customer obtains by participating in the innovation. Satisfaction.

\section{Virtual Customer Environment}

Customer participation innovation is mainly carried out through corporate websites or virtual communities. Nambisan defined Virtual Customer Environment (VCE) as the functions of customer and enterprise interaction for product development on the corporate website, he believes that customers create knowledge through VCE, and knowledge creation succeeds and otherwise depends on VCE system interaction ability [11]. Scholars' design guidelines for VCE are based on Flow Theory and Social Exchange Theory. Flow theory from a psychological point of view, when users participate in innovation through VCE, they are interested in fully investing in filtering out irrelevant perceptions. Social exchange theory refers to the principle that when a party (customer or enterprise) has a tendency to interact with the other party, it can benefit from the virtual interaction and is willing to abide by the principle of reciprocity. At this time, the enterprise customer forms an interactive group, virtual interaction started.

\section{HYPOTHESES AND THEORETICAL MODEL}

\section{A. Customer knowledge and customer participation in innovation}

Creative customer engagement provides new opportunities for companies to get new ideas about products in social media or virtual communities. Existing research indicates that selfefficacy, unique product needs, unique experience needs, and creative incentives all drive customers' willingness to engage in creative products and services. Scholars explored the impact of customer knowledge in the service industry on customer participation in innovation. Campel's study showed that in the process of customer participation, customers will feel certain risks to the service results affected by their own participation behavior, and these risks will reduce customer curiosity and exploratory behavior, thus reducing customers' willingness to participate [12]. Customer knowledge is considered a decisive factor in perceived risk and can reduce the extent of perceived risk [13]. The more knowledge they have, the more they think they can anticipate the outcome, reduce the perceived risk of the customer and stimulate the customer's exploratory behaviors such as new product innovation and manufacturing. Based on thus, I propose the first hypothesis:

H1: Customer knowledge has a positive impact on customer participation in innovation. 


\section{B. Virtual customer participation platform and customer participation in innovation}

As the new information technology, VCE fundamentally changes the way customers participate in product development, making it possible for customers to participate in product development in a comprehensive manner. Other scholars' research also shows that VCE can provide customers with fullfeatured online services, which facilitates product innovation and value creation for different types of customers at all stages of product development. For example, in the creative and design stage of innovation, the interaction and immediacy of the new media network enables customers to exchange development information in the experience of participating in innovation and testing new product stages [14]. The characteristics of virtual customer participation platform can enable customers to participate online product testing. It can reduce product development costs, speed up product development, increase product development and market efficiency, and ultimately lead to product development success.

Thus, I propose the first hypothesis:

$\mathrm{H} 2$ : VCE design features have a positive impact on customer engagement innovation.

\section{Customer participation in innovation and customer experience}

Customer participation in the innovation process is the premise of the customer experience. The various stages of enterprise innovation drive customer experience by guiding customer participation. The customer experience is unique to any customer, and participating in innovation allows the customer to take more initiative and bring about an improvement in all aspects of the experience. For example, when a customer participates in a creative design of a new product, the customer will actively participate in the collection of the creative activity, and it is more important to see other people's ideas can be exchanged to generate a social experience and emotional experience. When the customer participates in the new product test, customers can experience product features and services to create a functional experience. In addition to paying attention to the functional benefits of products or services, customers' participation in innovation also pays more attention to the specific experiences that are acquired in the process of innovation and meet their psychological needs and emotional preferences. Customers can participate in the innovation process to experience the good quality and functionality of new products or services, as well as to experience the psychological or emotional satisfaction of participating in innovative activities.

\section{Based on this, I propose the third hypothesis:}

H3: Customer involvement in innovation has a positive impact on the customer experience.

H3a: Customer engagement innovation has a positive impact on customer functional experience.

$\mathrm{H} 3 \mathrm{~b}$ : Customer involvement in innovation has a positive impact on the customer's social experience.
H3c: Customer involvement in innovation has a positive impact on the customer's emotional experience.

\section{Customer participation in innovation plays a mediating role in the relationship between customer knowledge and customer experience.}

Faced with the challenges of the knowledge economy, the management of customer knowledge has become a key resource for marketing innovation and thus to enhance the core competitiveness of enterprises. Today, when the Internet, social media and virtual communities are booming, companies create an environment for customers to encourage them to participate in new product innovations. High-skilled customers will actively participate in creative design and development by using their knowledge because of perceived risk reduction. The active participation of customers enables them to obtain psychological needs or emotional preferences to satisfy the customer's functional, social and emotional experience.

Based on this, I propose the fourth hypothesis:

H4: Customer engagement innovation plays a mediating role in customer knowledge and customer experience.

The research model tested in this study is shown in Figure 1.

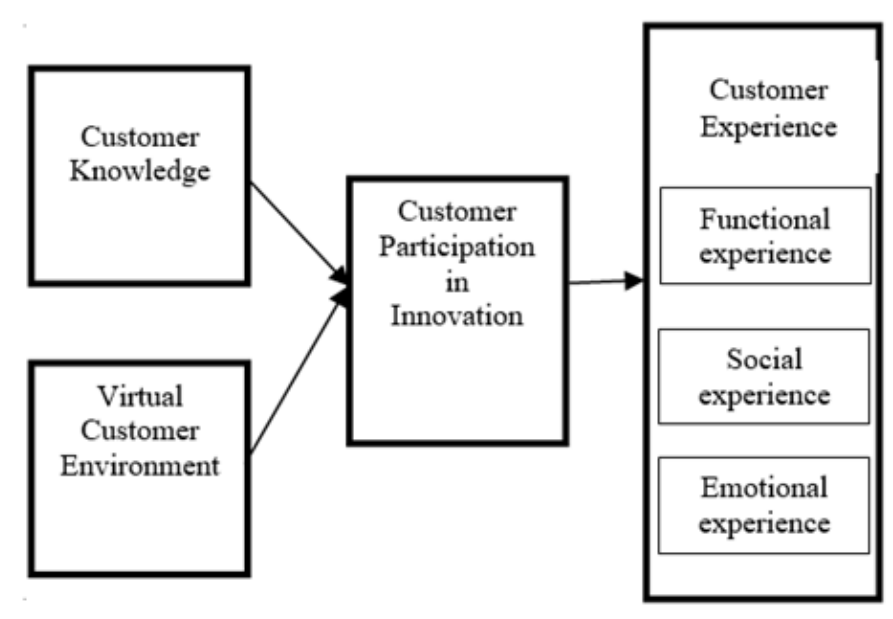

Fig. 1 Theoretical model

\section{CONCLUSION AND LIMITATION}

In the context of the new media environment, this paper explores the relationship between customer knowledge, customer participation in innovation and customer experience. The increase in customer knowledge can reduce the perceived risk of customers, so customers are more willing to participate in the process of new product development. The development of the virtual participation platform has enabled customers to change the way they participate in the product. With the interaction and immediacy of the social network, customers can participate in the development and testing of products on the network, which enables the company to produce customers with lower cost at a lower cost. Products, customers are also more willing to participate in the process of product innovation. 
So customer knowledge and virtual customer engagement platforms can make customers more willing to participate in innovation. In addition to paying attention to the functional benefits of products or services, customer participation in innovation also pays more attention to the specific experiences that are acquired in the process of innovation and meet their psychological needs and emotional preferences. Therefore, customers can participate in the innovation process to experience the good quality and function of new products or services, as well as to experience the psychological or emotional satisfaction of participating in innovative activities. From the dynamic perspective, the experience in the customer innovation process can better reflect the real feelings of customers, and positive customer innovation activities have a positive impact on the customer experience.

The implications of this research for business management and practice include:

(1) Enterprises should pay attention to the importance of customer knowledge, focus on cultivating customer knowledge, and thus reduce the uncertainty of customer participation, making customers more willing to participate in the process of product innovation. (2) With the development of emerging technologies, companies should pay attention to the importance of these social media, and use social media software to allow customers to have new channels of communication with enterprises. (3) Enterprises need to pay attention to the impact of customer innovation on customer experience in the process of customer innovation. This helps the company design the customer management system, input continuous and dynamic resources, and continuously promote customer experience.

This paper only builds a theoretical framework of the relationship between customer knowledge, customer participation innovation and customer experience based on the existing literature, and does not conduct empirical research. In the future, it can be further explored through interviews, questionnaires and other empirical research methods. At the same time, future research should further explore the impact of customer experience on corporate innovation performance and the corresponding mechanism.

\section{REFERENCES}

[1] Joshi A W, Sharma S. Customer Knowledge Development: Antecedents and Impact on New Product Performance[J]. Journal of Marketing, 2004, 68(4):47-59.

[2] Satu Nätti, Jukka Ojasalo. What prevents effective utilisation of customer knowledge in professional B-to-B services? An empirical study[J]. Service Industries Journal, 2008, 28(9):1199-1213.

[3] Bueren A, Schierholz R, Kolbe L, et al. Customer Knowledge Management - Improving Performance of Customer Relationship Management with Knowledge Management[C]// Proceedings of the, Hawaii International Conference on System Sciences. IEEE Computer Society, 2004:70172.2.

[4] Smith H A, Mckeen J D. Developments in practice XVIII-customer knowledge management: Adding value for our customers[J]. Communications of the Association for Information Systems, 2005.

[5] Brodie, Frow, Hughes, et al. Resource Integration[J]. Marketing Theory, 2012, 12(2):201-205.

[6] Lau A K W, Tang E, Yam R C M. Effects of Supplier and Customer Integration on Product Innovation and Performance: Empirical Evidence in Hong Kong Manufacturers [J]. Journal of Product Innovation Management, 2010, 27(5):761-777.

[7] Baldus B J, Voorhees C, Calantone R. Online brand community engagement: Scale development and validation[J]. Journal of Business Research, 2015, 68(5):978-985.

[8] M. Young, The Technical Writer's Handbook. Mill Valley, CA: University Science, 1989.

[9] 2Nd P B, Gilmore J H. Welcome to the experience economy[J]. Harvard Business Review, 1998, 76(4):97.

[10] Rose S, Hair N, Clark M. Online Customer Experience: A Review of the Business-to-Consumer Online Purchase Context[J]. International Journal of Management Reviews, 2011, 13(1):24-39.

[11] Nambisan S. Designing virtual customer envionments for new product development:towards a theory [J]. Academy of Management Review, 2002, 27(3):392-413.

[12] Campbell M C, Goodstein R C. The Moderating Effect of Perceived Risk on Consumers' Evaluations of Product Incongruity: Preference for the Norm.[J]. Journal of Consumer Research, 2001, 28(3):439-449.

[13] Dowling G R, Staelin R. A Model of Perceived Risk and Intended Riskhandling Activity [J]. Journal of Consumer Research, 1994, 21(1):119134.

[14] Ozer M. Process implications of the use of the Internet in new product development: a conceptual analysis[J]. Industrial Marketing Management, 2003, 32(6):517-530. 